\title{
Lack of Interferon- $\gamma$ Production Despite the Presence of Interleukin-18 During Cutaneous Wound Healing
}

\author{
Heiko Kämpfer, Jens Paulukat, Heiko Mühl, Christian Wetzler, \\ Josef Pfeilschifter, and Stefan Frank \\ pharmazentrum Frankfurt, Klinikum der Johann Wolfgang Goethe-Universität, \\ Frankfurt am Main, Germany
}

Accepted August 1, 2000.

\begin{abstract}
Background: Recently, we have reported a rapid and strong induction of interleukin-18 (IL-18) upon cutaneous injury in mice. In this paper, we investigated a possible role of IL-18 in triggering interferon- $\gamma($ IFN- $\gamma)$ production at the wound site.

Materials and Methods: Expression of IFN- $\gamma$ during cutaneous wound healing was analyzed by RNase protection assay, Western blot, ELISA, and immunohistochemical techniques in a murine model of excisional skin repair.

Results: We could not detect any IFN- $\gamma$ mRNA and protein expression during normal skin repair. Additionally, impaired healing in the genetically diabetic $d b / d b$ mouse, which was used as a model for a prolonged inflammatory phase of repair, was characterized by largely elevated levels of IL-18 during the late phase of repair and an absence of IFN $-\gamma$. Western
\end{abstract}

blot analysis for T-cell- and monocyte/macrophagespecific marker proteins (CD4, F4/80) clearly revealed the presence of these subsets of leukocytic cells at the wound site, that are known to produce IFN- $\gamma$ in response to IL-18. Furthermore, we provide evidence that the presence of transforming growth factor- $\beta$ l (TGF- $\beta 1$ ) at the wound site might reflect a counterregulatory mechanism in IL-18induced IFN- $\gamma$ production, as TGF- $\beta$ I strongly suppressed IL-18/phytohaemagglutinin (PHA)-induced IFN- $\gamma$ production by peripheral blood mononuclear cells (PBMC) in vitro.

Conclusions: Normal tissue regeneration processes after cutaneous injury were not dependent on the presence of IFN- $\gamma$ in vivo, and IL-18 must serve additional roles rather than inducing IFN- $\gamma$ during the healing process.

\section{Introduction}

Interferon (IFN)- $\alpha,-\beta$, and - $\gamma$ represent modulators of fibrous responses for a variety of mesenchymal cells in vitro. Especially, all three IFN-isoforms are well known to be capable of reducing collagen synthesis by dermal fibroblasts (1-3). Thus, the IFNs have been implicated in the tight regulation of a balanced synthesis and degradation of collagen, which has to be transiently altered in processes such as cutaneous wound repair, or which seems to be

Address correspondence and reprint requests to: Stefan Frank, pharmazentrum Frankfurt, Klinikum der JWG-Universität Frankfurt/M., Theodor-Stern-Kai 7,

D-60590 Frankfurt/M., Germany. Phone: 069-6301-6954;

Fax: 069-6301-7942; E-mail: S.Frank@em.uni-frankfurt.de dysregulated in pathological processes of the skin such as scleroderma or keloid formation (4-6). Interestingly, IFN- $\gamma$ has been implicated in epidermal keratinocyte proliferative hemostasis, as an antiproliferative effect of IFN- $\gamma(7)$ might be attenuated by reduced numbers of IFN- $\gamma$ receptors in psoriatic lesions (8). Interferon- $\gamma$ efficiently established a reduced-collagenproducing phenotype in cultured scleroderma fibroblasts (2), and long-term clinical studies indeed revealed a beneficial effect of recombinant IFN- $\gamma$ in scleroderma patients $(9,10)$. Further in vivo experiments supported a possible role of IFN- $\gamma$ for the treatment of disease states characterized by excessive fibrosis. Thus, subcutaneously implanted osmotic pumps delivering recombinant IFN- $\gamma$ were not encapsulated 
by excessive collagen matrices in mice (11). Moreover, using a murine wound-healing model, systemic administration of IFN- $\gamma$ upon injury decreased wound collagen deposition and clearly reduced the initial inflammatory response (12) indicating a role for this mediator in the control of excessive matrix synthesis during repair.

Although macrophages (13) and epidermal keratinocytes (14) have been reported to produce IFN- $\gamma$, T-lymphocytes are regarded as the main source of IFN- $\gamma$-production during inflammatory processes. In the mouse, $\mathrm{T}$ helper (Th) cells may be broadly divided into two subclasses based on the cytokine patterns they secrete (15). Consistently, the Thl subtype is characterized by a predominant secretion of IFN- $\gamma$ and IL-2 (16). Following the preceding neutrophils and macrophages, T-cells peak within cutaneous wounds around day 7 after injury $(17,18)$. Interestingly, global T-cell depletion caused a marked reduction in mechanical strength and collagen content of rat cutaneous wounds (19). As IFN- $\gamma$ clearly reduced wound collagen synthesis (12), the absence of IFN- $\gamma$-producing lymphocytes should lead to opposite effects. Moreover, as expression of the IFN- $\gamma$-inducing cytokine IL-18 temporally precedes the infiltration of T-lymphocytes upon injury (20), we raised the question of a general presence of IFN- $\gamma$ during cutaneous healing.

In this study, we have investigated the expression pattern of IFN- $\gamma$ during cutaneous wound repair. Remarkably, we could not detect IFN- $\gamma$ mRNA and protein during the complete process of tissue regeneration. Moreover, we provide evidence that up-regulation of TGF- $\beta 1$ during repair might reflect a counterregulatory mechanism that suppresses IFN- $\gamma$ production in wound lymphocytes. Our data suggest that a normal repair is characterized by the suppression of IFN- $\gamma$ production, and, thus, our findings might provide an explanation for the wound healing deteriorations observed for IFN- $\gamma$-treated wounds (12).

\section{Materials and Methods}

Animals

Female C57BLKS $/ \mathrm{J}-m+/+$ Lepr $^{d b}$ mice obtained from Jackson Laboratories (Bar Harbor, ME, USA) were chosen because they exhibit characteristics similar to those of human adult onset diabetes as a result of single autosomal recessive mutation on chromosome 4 . This mutation inhibits signal transduction of the leptin receptor ObR (21-23). Only the homozygous animals develop diabetes (21). Female Balb/c mice were used as controls representing a normal, nondiabetic repair process. All animals were 10 weeks of age at the start of the experiment.

\section{Wounding and Preparation of Wounds}

To examine IFN- $\gamma$ expression during a normal and impaired wound-healing process, six fullthickness wounds were created on the backs of female Balb/c or C57BLKS/J-m $+/+L_{e p r}{ }^{d b}$ mice. Animals were anesthetized with a single intraperitoneal injection of Ketamin $(80 \mathrm{mg} / \mathrm{kg}$ body weight)/Xylazin ( $10 \mathrm{mg} / \mathrm{kg}$ body weight). The hair on the back of these mice were cut, and the back was subsequently wiped with $70 \%$ ethanol. Six full-thickness wounds $(5 \mathrm{~mm}$ in diameter, 3-4 $\mathrm{mm}$ apart) were made on the backs of these mice by excising the skin and the underlying panniculus carnosus. The wounds were allowed to form a scab. Skin biopsy specimens from four animals were obtained 1, $3,5,7$, and 13 days after injury. An area of 7-8 $\mathrm{mm}$ in diameter, which included the scab and the complete epithelial margins, was excised at each time point. As a control, a similar amount of skin was taken from the backs of four nonwounded mice. In every experiment, the wounds from four animals ( $n=16$ wounds) and the nonwounded back skin from four animals, respectively, were combined, frozen immediately in liquid nitrogen, and stored at $-80^{\circ} \mathrm{C}$ until used for RNA or protein isolation. All animal experiments were carried out according to the guidelines and with the permission from the local government of Hessen.

\section{Immunohistochemistry}

Mice were wounded as described previously. Animals were sacrificed at day 7, as T-lymphocytes are described to peak at the wound site at this time point after injury $(17,18)$. Complete wounds were isolated from the middle of the back, bisected, and frozen in tissue freezing medium. Six micrometer frozen serial sections were fixed with acetone and treated for $10 \mathrm{~min}$ at room temperature with $1 \% \mathrm{H}_{2} \mathrm{O}_{2}$ in phosphate-buffered saline to inactivate endogenous peroxidases. They were subsequently incubated 
for $60 \mathrm{~min}$ at room temperature with a polyclonal anti-serum against murine IFN- $\gamma$ (R\&D systems, Wiesbaden, Germany) 1:50 diluted in phosphate-buffered saline, $0.1 \%$ goat serum albumine. The slides were subsequently stained with the avidin-biotin-peroxidase complex system from SantaCruz (Heidelberg, Germany) using 3-amino-9-ethylcarbazole as a chromogenic substrate. After development, they were rinsed with water, counterstained with hematoxylin (Sigma, Deisenhofen, Germany), and mounted. Frozen sections from spleen isolated from endotoxin-treated mice were incubated with the same antibody as a positive control to assess the validity of the polyclonal anti-IFN- $\gamma$ antibody.

\section{Preparation of Tissue Lysates}

and Western Blot Analysis

Skin samples were homogenized in lysis buffer ( $1 \%$ Triton X-100, $20 \mathrm{mM}$ Tris/HCl, pH 8.0, $137 \mathrm{mM} \mathrm{NaCl}, 10 \%$ glycerol, $5 \mathrm{mM}$ ethylendiamine tetraacetic acid, $1 \mathrm{mM}$ phenylmethylsulfonyl fluoride, $1 \%$ aprotinin, $15 \mu \mathrm{g} / \mathrm{ml} \mathrm{leu-}$ peptin). The tissue extract was cleared by centrifugation. Fifty micrograms of total protein from these lysates was separated using sodium dodecyl sulfate-gel electrophoresis. After transfer to a PVDF membrane, CD4 protein was detected by a polyclonal antibody raised against human CD4 (Santa Cruz, Heidelberg, Germany), macrophage-specific F4/80 protein was determined using a monoclonal antibody raised against murine F4/80 antigen (Serotec, Hamburg, Germany), or IFN- $\gamma$ protein was detected using the polyclonal antibody as described under the section on Immunohistochemistry. IL-18-specific proteins were detected using a monoclonal antibody as described recently (20). A secondary antibody coupled to horseradish peroxidase and the ECL detection system were used to visualize the proteins. Phenylmethylsulfonyl fluoride, aprotinin, and leupeptin were from Sigma (Deisenhofen, Germany), and the ECL detection system was obtained from Amersham (Freiburg, Germany).

\section{RNA Isolation and RNase Protection Assay}

RNA isolation was performed as described (24). Twenty micrograms of total RNA from wounded or nonwounded skin were used for RNase protection assays. RNase protection assays were carried out as described (25). Protected fragments were separated on $5 \%$ acryl- amide/8 M urea gels and analyzed using a PhosphoImager (Fuji, Straubenhardt, Germany).

\section{Probe $C D N A s$}

The murine cDNA probes for interferon- $\gamma$ (IFN$\gamma)$, transforming growth factor $\beta 1$, or chymase, respectively, were cloned by reverse-transcriptase polymerase chain reaction (RT-PCR). The cloned cDNA fragments correspond to nucleotides 248497 (for IFN- $\gamma$ ), nucleotides 1735-1974 (for TGF- $\beta 1$ ), or nucleotides 463-704 (for chymase) of the published sequences $(26,27$; and EMBL. Acc. No. NM011577 for TGF- $\beta 1$ ).

Enzyme-linked Immunosorbent Assay for Wound-derived IFN- $\gamma$

Total protein ( $25 \mu \mathrm{g}$ diluted in lysis buffer (w/o Triton X-100) to a final volume of $50 \mu \mathrm{l}$ ) from nonwounded skin lysates and wound lysates were subsequently analyzed for the presence of immunoreactive IFN- $\gamma$ protein by enzymelinked immunosorbent assay (ELISA) using the Quantikine murine IFN- $\gamma$ kit (RED Systems, Wiesbaden, Germany) as described by the manufacturer.

\section{Isolation of Peripheral Blood Mononuclear Cells}

The study protocol and consent documents were approved by the Ethik Kommission of the Klinikum der Johann Wolfgang GoetheUniversität, Frankfurt am Main. Healthy volunteers abstained from any drugs during the 2 weeks before the study. Peripheral blood mononuclear cells (PBMC) were isolated as previously described (28). For experiments with PBMC, cells were resuspended in RPMI 1640 supplemented with $25 \mathrm{mM}$ HEPES, $100 \mathrm{U} / \mathrm{ml}$ penicillin, $100 \mu \mathrm{g} / \mathrm{ml}$ streptomycin (Gibco-BRL, Eggenstein, Germany), and $1 \%$ (v/v) heat-inactivated human $A B$ serum (Sigma Deisenhofen, Germany), and seeded at $3 \times 10^{6}$ cells $/ \mathrm{ml}$ in round-bottom polypropylene tubes. Induction experiments were performed using human recombinant IL-18 (PeproTec, Frankfurt, Germany), and phytohaemagglutinin (PHA) from Roche Biochemicals (Mannheim, Germany).

Enzyme-linked Immunosorbent Assay for PBMC-Derived IFN- $\gamma$

Levels of IFN- $\gamma$ in cell-free culture supernatants were determined by ELISA (Pharmingen, 
Hamburg, Germany) according to the manufacturers instructions.

\section{Results \\ Temporal Correlation Between IL-18 Protein Expression and the Presence of Th Cells and Macrophages During Normal and Impaired Wound Healing}

Major biologic properties of IL-18 are represented by its ability to stimulate IFN $-\gamma$ production and Thl cell differentiation (29). Moreover, murine macrophages respond also to an IL-18 stimulus with the production of large amounts of IFN- $\gamma(13)$. Thus, it becomes obvious that the appearance of IL-18 must be closely correlated to these subsets of infiltrating leukocytes in a temporal manner during cutaneous healing to subsequently trigger IFN$\gamma$ production by the cells. For this reason, we determined the time course of IL-18 expression during normal repair. Moreover, as the production of IFN- $\gamma$ might be associated with the inflammatory phase of repair, we have determined IL-18 expression and immigration of the Th/macrophage subset of leukocytes during healing in the genetically diabetic $d b / d b$ mouse, which is characterized by a prolonged inflammatory phase of repair (30). Consistent with previous data (20), we observed a rapid and strong increase in IL-18 protein upon injury, which is most likely to represent the unprocessed, immature $24 \mathrm{kDa}$ pro-IL-18 precursor form (Fig. 1A, lower panel). Remarkably, diabetes-impaired healing was characterized by prolonged and strongly elevated levels of IL-18 protein (Fig. 1B, lower panel). To determine the presence of Th leukocytes, a cell type potentially capable of producing IFN- $\gamma(29)$ in the wound, we used the CD4 receptor as a marker protein that is expressed in this cell type (31). Moreover, as IL-18-stimulated monocytic cells also have been described to produce IFN- $\gamma$ (13), we additionally determined the presence of F4/80 antigen at the wound site, which represents a $160-\mathrm{kDa}$ glycoprotein that is specifically expressed by murine macrophages (32). Although IL-18 protein levels started to decline from day 3 after injury in normal wounds, there was clear evidence that infiltrating Th cells (as assessed by $C D 4$ expression; Fig. 1A, upper panel) and macrophages (as assessed by F4/80 expression; Fig. 1A, middle panel) were still exposed to elevated levels of IL-18 protein at day 5 and 7 postwounding (Fig. 1A, lower panel). As the CD4 antibody unspecifically detects a major band of approximately $90 \mathrm{kDa}$ in total wound lysates, we have used total protein from lysates of human PBMC as a positive control for CD4 protein detection by this antibody (Fig. 1A, PBMC lane). Diabetesimpaired healing was characterized by a close temporal correlation between the presence of IL-18, the infiltration of Th leukocytes and, moreover, a prolonged presence of monocytic cells at the wound site, thus generating a prerequisite for the induction of IFN- $\gamma$ (Fig. 1B).

\section{Lack of IFN- $\gamma$-induction During Normal and Impaired Cutaneous Wound Repair}

As a next step, we determined whether the observed high levels of IL-18 in the presence of Th cells and macrophages might trigger the subsequent induction of IFN- $\gamma$ at the wound site. Moreover, it was tempting to speculate that the observed differences in IL-18 expression patterns that met Th cells and macrophages during normal or impaired repair (see Fig. 1) might result in different expression levels of IFN- $\gamma$. Despite the observed presence of IL-18 and these cells, unexpectedly, we could not identify any IFN- $\gamma$-specific signals at the mRNA level by the sensitive RNase protection method for both the normal (Fig. 2A, upper panel) and, additionally, the diabetes-impaired (Fig. 2A, lower panel) wound-healing processes. As a control, we simultaneously hybridized a GAPDH antisense with the same sets of RNA. Note that we indeed could confirm the functionality of the murine IFN- $\gamma$ probe, as we obtained a strong signal in total RNA from spleen isolated from a LPS-treated mouse that was used as a positive control for IFN- $\gamma$-expression (Fig. 2A, upper right panel). Consistently, we could not detect any IFN- $\gamma$-specific signals in total protein (50 $\mu \mathrm{g}$ loaded) of wound lysates isolated from wild-type (Fig. 2B, upper panel) or diabetic (Fig. 2B, lower panel) animals. Note that the antibody indeed recognized recombinant murine IFN- $\gamma$, which has been loaded on the same gels as a positive control. To further confirm the absence of IFN- $\gamma$ in cutaneous wounds of normal and diabetic animals, we assessed wound lysates of these animals for the presence of IFN- $\gamma$-specific proteins using ELISA. As shown in Table 1, we could not detect any IFN- $\gamma$ throughout all wound-healing time points examined. That means that the amounts 


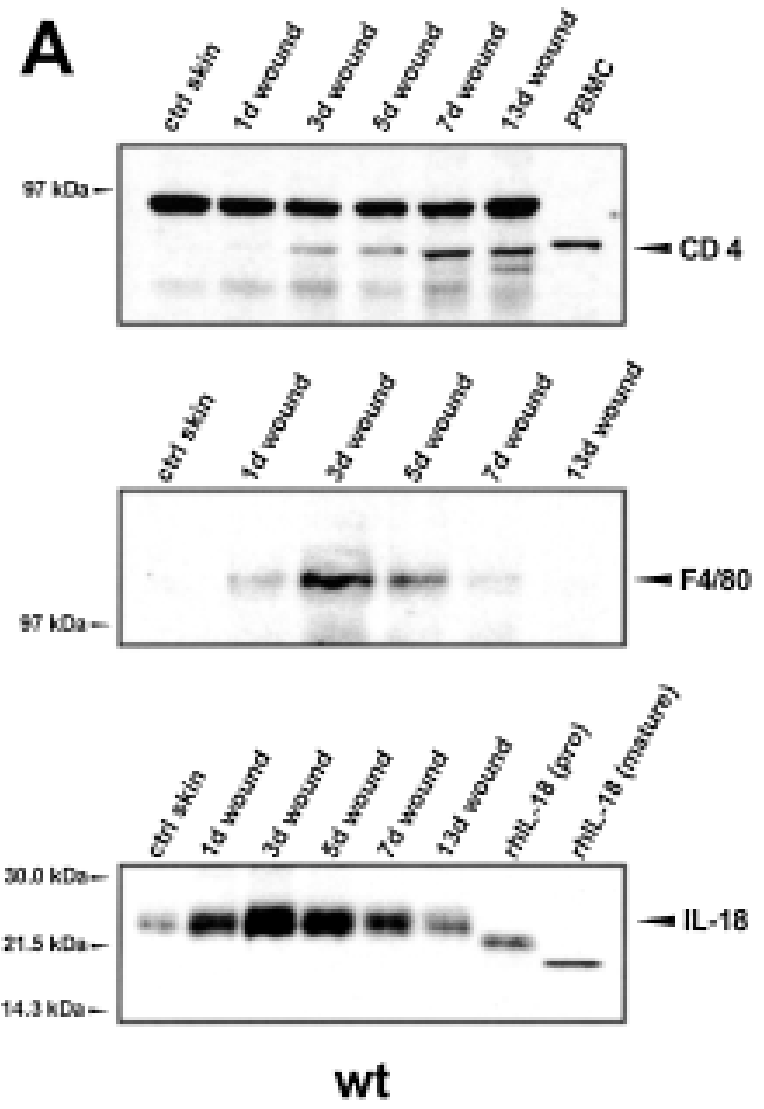

Fig. 1. Temporal correlation between IL-18 protein expression and the presence of $T h$ cells and macrophages during normal and impaired wound repair. Total protein $(50 \mu \mathrm{g})$ from lysates of nonwounded and wounded back skin (days 1, 3, 5, 7, and 13 after injury, indicated at the top of each lane) of Balb/c mice (A, indicated as $w t)$, or $\mathrm{db} / \mathrm{db}$ mice $(\mathrm{B}$, indicated as $d b)$ were analyzed by immunoblotting for the presence of CD4 (upper panels), F4/80 antigen (middle panels), or IL-18 protein (lower panels), respectively. Four wounds $(n=4)$ from the backs of four animals were

of IFN- $\gamma$ protein in wound lysates of all examined time points were beneath the lowest IFN$\gamma$-standard concentrations used, and, therefore, beneath the detection limit of $3 \mathrm{pg} / \mathrm{ml}$ as given by the manufacturer. To control the reliability of the assay, we were able to measure and, thus, specifically detect murine recombinant IFN- $\gamma$, which has been added to 1-day wound lysates prior to the measurement (Table 1).

As we could not detect IFN- $\gamma$ using RNase protection assay, Western blot analysis and ELISA, we additionally performed immunohistochemistry on frozen serial sections from isolated 7-day wounds (Fig. 3A). For this purpose, we treated $6-\mu \mathrm{m}$ frozen sections with the antibody against murine IFN- $\gamma$. As shown in
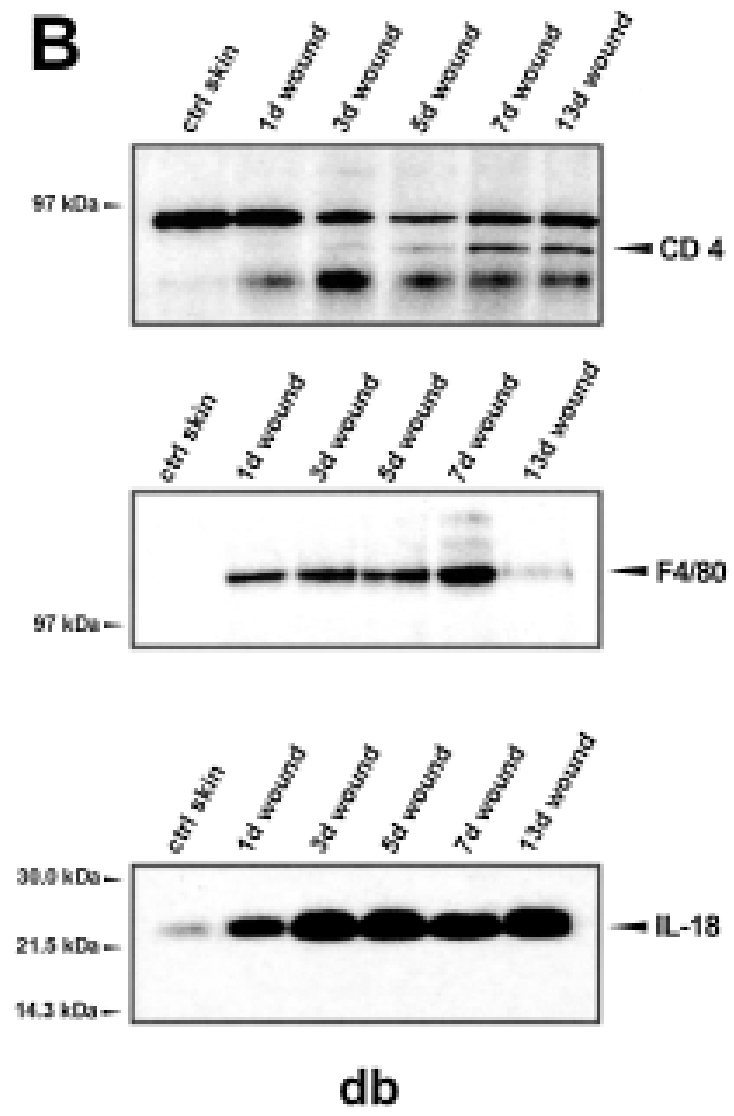

excised for each experimental time point and used for protein isolation. CD4, F4/80, or IL-18 protein is indicated by an arrow. As the anti CD4-antibody unspecifically detects a major band of approximately $90 \mathrm{kDa}$ in wound lysates, we have used total protein from lysates of human PBMC as a positive control for $\mathrm{CD} 4$ protein detection by this antibody (A, PBMC lane). Recombinant human pro[rhIL-18(pro)] and mature [rhIL-18(mature)] IL-18 was used as a positive control for the anti-IL-18 antibody. One representative immunoblot is shown for each condition.

Figure 3A, we could not observe any anti-IFN- $\gamma$ immunolabeled cells within the granulation tissue, and, thus, immunohistochemistry analysis further strengthens the observation of missing IFN- $\gamma$ expression during skin repair. To assess the validity of the lacking immunopositive staining for IFN- $\gamma$ in the skin sections, we used frozen sections from spleen obtained from a LPS-treated mouse as a positive control for IFN- $\gamma$ expression (Fig. 3B).

Strong and Constitutive Expression of Chymase During Repair

As we had observed IL-18 protein to appear mainly in the unprocessed pro-IL-18 form 


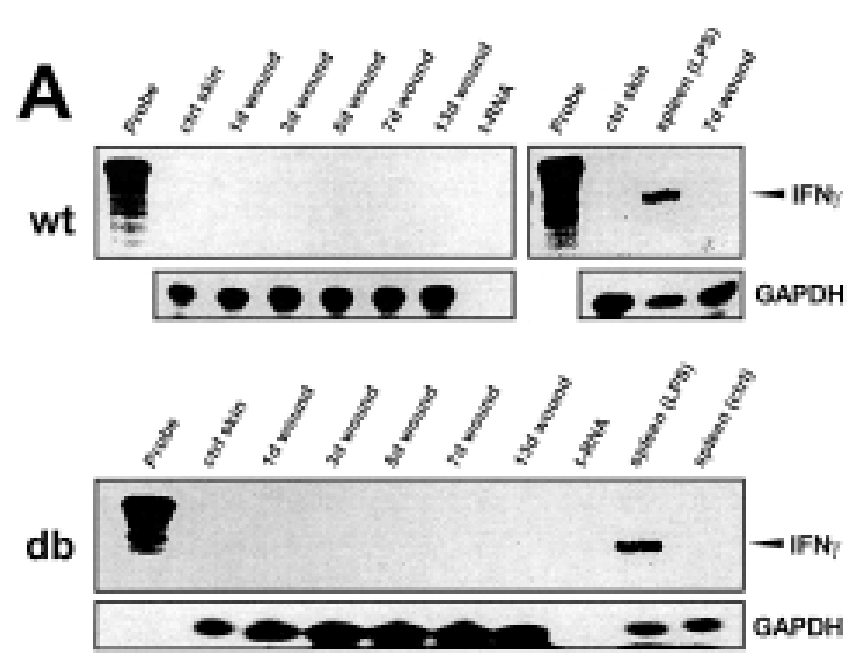

Fig. 2. IFN- $\boldsymbol{\gamma}$ mRNA and protein expression is not detectable during skin repair. (A) Total cellular RNA $(20 \mu \mathrm{g})$ from normal and wounded back skin was analyzed by RNase protection assay for expression of IFN- $\gamma$. The complete absence of IFN- $\gamma$ mRNA expression in normal Balb/c mice (upper panel, indicated as $w t$ ), or diabetic animals (lower panel, indicated as $d b$ ) is shown. Sixteen wounds $(n=16)$ from the backs of four animals were excised for each experimental time point and used for RNA isolation. The time after injury is indicated at the top of each lane. Control skin refers to nonwounded skin of mice. One thousand cpm of the hybridization probe were added to the lane labeled probe. To verify the functionality of the used IFN- $\gamma$-antisense RNA probe, we hybridized

Table 1. Quantification of IFN- $\gamma$ protein expression in wound lysates isolated from normal and diabetic animals

\section{IFN $\gamma$-Content}

\begin{tabular}{ll}
\hline ctrl skin $(\mathrm{wt}, \mathrm{db})$ & $<\mathrm{d} .1$. \\
$1,3,5,7,13 \mathrm{~d}$ & $<\mathrm{d} .1$. \\
$\quad$ wound $(\mathrm{wt}, \mathrm{db})$ & \\
ld wound $(25 \mu \mathrm{g})$ & $61 \mathrm{pg}$ \\
$\quad+50$ pg rec. mlFN $\gamma$ &
\end{tabular}

Total protein $(25 \mu \mathrm{g})$ from lysates of nonwounded and wounded back skin (day 1, 3, 5, 7, and 13 after injury as indicated) isolated from Balb/c mice (wt) and diabetic mice $(d b)$ were assessed for the total amount of IFN- $\gamma$-specific proteins dring wound repair as determined by ELISA (R\&D Systems). Eight wounds $(n=8)$ from the backs of four animals were excised for each experimental time point and used for protein isolation. Addition of $50 \mathrm{pg}$ recombinant murine IFN- $\gamma$ to 1-day wound lysates was used to verify the functionality of the IFN- $\gamma$-ELISA. $<$ d.1., below detection limit.

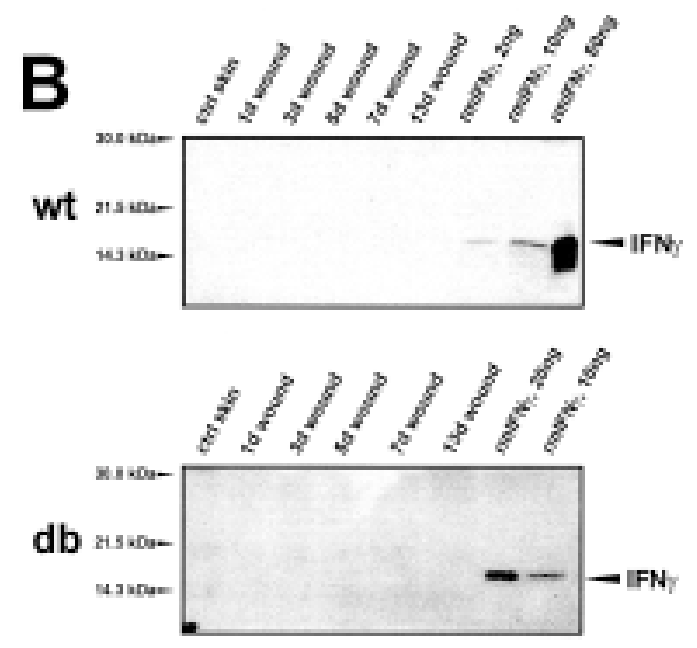

the IFN- $\gamma$ probe to total RNA isolated from the spleen of an endotoxin (LPS)-treated mouse (spleen, LPS). Expression of GAPDH mRNA is shown as a loading control for both experiments. (B) Total protein $(50 \mu \mathrm{g})$ from lysates of nonwounded and wounded back skin (days 1, 3, 5, 7, and 13 after injury, indicated at the top of each lane) of Balb/c mice (indicated as $w t$ ), or $\mathrm{db} / \mathrm{db}$ mice (indicated as $d b$ ) were analyzed by immunoblotting for the presence of IFN- $\gamma$. Four wounds $(n=4)$ from the backs of four animals were excised for each experimental time point and used for protein isolation. We have used different amounts of recombinant murine IFN- $\gamma$ as a positive control (indicated by an arrow). One representative immunoblot is shown for each condition.
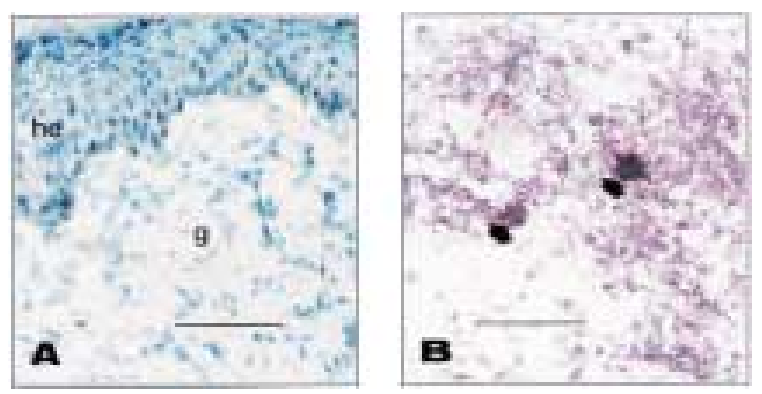

Fig. 3. IFN- $\gamma$ is not expressed at the wound site. (A) Frozen serial sections from 7-day mouse wounds were isolated from Balb/c animals. Sections were incubated with a polyclonal antiserum directed against murine IFN- $\gamma$. All sections were stained with the avidin-biotin-peroxidase complex system using 3-amino-9-ethylcarbazole as a chromogenic substrate. Nuclei were counterstained with hematoxylin. Scale bar $=50 \mu \mathrm{m}$. IFN- $\gamma$ immunopositive signals within the sections could not be detected (he, hyperproliferative epithelium; $g$, granulation tissue). (B) A frozen serial section from the spleen of an endotoxin (LPS)-treated mouse was used as a positive control for the validity of the antiIFN- $\gamma$ anti-serum. Strongly IFN- $\gamma$-immunopositive cells were indicated by arrows. Scale bar $=25 \mu \mathrm{m}$. 


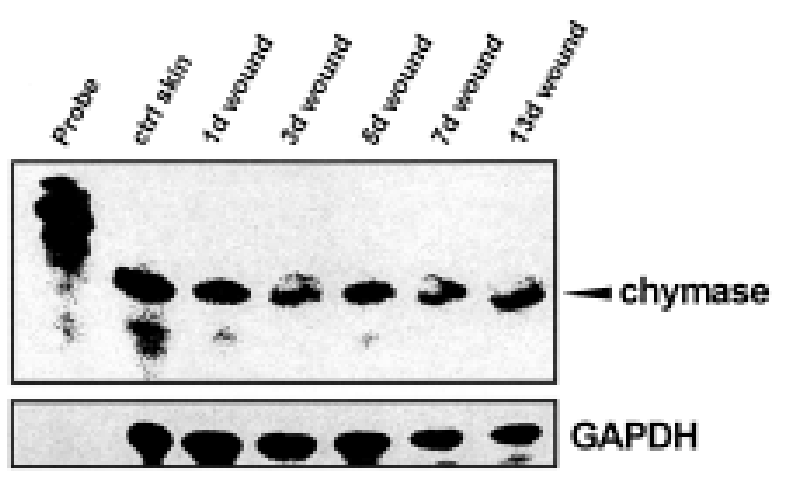

Fig. 4. Expression pattern of chymase during repair. Total cellular RNA (30 $\mu \mathrm{g})$ from normal and wounded back skin from Balb/c mice was analyzed by RNase protection assay for expression of mast cell-derived chymase. Sixteen wounds $(n=16)$ from the backs of four animals were excised for each experimental time point and used for RNA isolation. The time after injury is indicated at the top of each lane. Control skin refers to nonwounded skin of mice. One thousand cpm of the hybridization probe were added to the lane labeled probe. One representative experiment is presented. Expression of GAPDH mRNA is shown as a loading control.

during repair, the absence of mature IL-18 might provide an explanation for the lack of IFN- $\gamma$-inducing activity. As it has been shown that proteases associated with inflammatory conditions such as chymase, cathepsin, elastase, or matrix metalloproteinases (MMP) were capable to convert the unprocessed IL-1 $\beta$ precursor into the mature and active form (33-35), pro-IL-18 also may be cleaved by these non-IL$1 \beta$-converting-enzymes (ICE) in the context of repair. As the expression of MMPs have been well described for the healing process (36), we additionally determined the possible presence of a second type of protease, namely, mast cellderived chymase, at the wound site. As shown in Figure 4, we observed a strong and constitutive expression of chymase mRNA during skin repair. These data indicate, indeed, the expression of enzymes with suggested pro-IL-18 converting properties within the wound.

\section{TGF- $\beta 1$ Strongly Attenuates IL-18/PHA-induced} IFN- $\gamma$ Production by PBMC

Interestingly, we could not detect IFN- $\gamma$ expression during wound healing despite the presence of mononuclear cells and IL-18 at the wound site. As IFN- $\gamma$ represents a negative regulator of collagen production in fibroblasts (1-3), and, by contrast, TGF- $\beta 1$ stimulates wound fibroblasts to synthesize a new collagenrich matrix (37), we assessed the possibility that the presence of TGF- $\beta 1$ at the wound site (38) might reduce leukocyte-derived IFN- $\gamma$ production. For this purpose, we isolated and cultured human peripheral blood mononuclear cells (PBMC). Costimulation of cells with PHA/IL-18 led to a dramatic release of IFN- $\gamma$ by the cells (Fig. 5A). The same experiment has been repeated with an IL-12/IL-18 stimulus which also led to an intense production of IFN- $\gamma$ (data not shown). More important, simultaneous addition of TGF- $\beta 1$ to stimulated PBMC resulted in a more than $75 \%$ reduction in IFN- $\gamma$ release from cultured cells of all donors (Fig. 5A). Thus, TGF- $\beta 1$ indeed represents a potent inhibitor of IFN- $\gamma$ production in vitro.

\section{Strong Expression of TGF- $\beta 1$ During Normal and Impaired Healing}

Finally, we investigated the presence of TGF$\beta 1$ during cutaneous repair in vivo to strengthen the in vitro observations of TGF- $\beta 1$ as an inhibitor of IFN- $\gamma$ production. Previously, we have demonstrated a strong induction of TGF- $\beta 1$ during normal repair (38), and neutralization studies against the three TGF- $\beta$-isoforms clearly demonstrated a functional role of the factors for skin repair in a rat model of cutaneous healing (39). However, the situation for diabetes-impaired healing remains unclear. As shown in Figure 5B (upper panel), we assessed an induction of TGF- $\beta 1$ during normal repair, thus confirming our previous report (38). Moreover, also diabetes-impaired healing in $d b / d b$ mice was characterized by a strong presence of TGF- $\beta 1$ during repair (Fig. 5B, lower panel) indicating that this mediator might be responsible, at least partially, for the observed absence of IFN- $\gamma$ during impaired healing conditions.

\section{Discussion}

Wound healing represents a highly dynamic process finally leading to an imperfect regeneration of the injured tissue. One central process of tissue regeneration is the formation of granulation tissue, starting about 3 to 4 days after injury (36). The main cell types driving the generation of new stroma are macrophages and fibroblasts, and interaction of these cell types leads to deposition of newly synthesized connective tissue. 
A
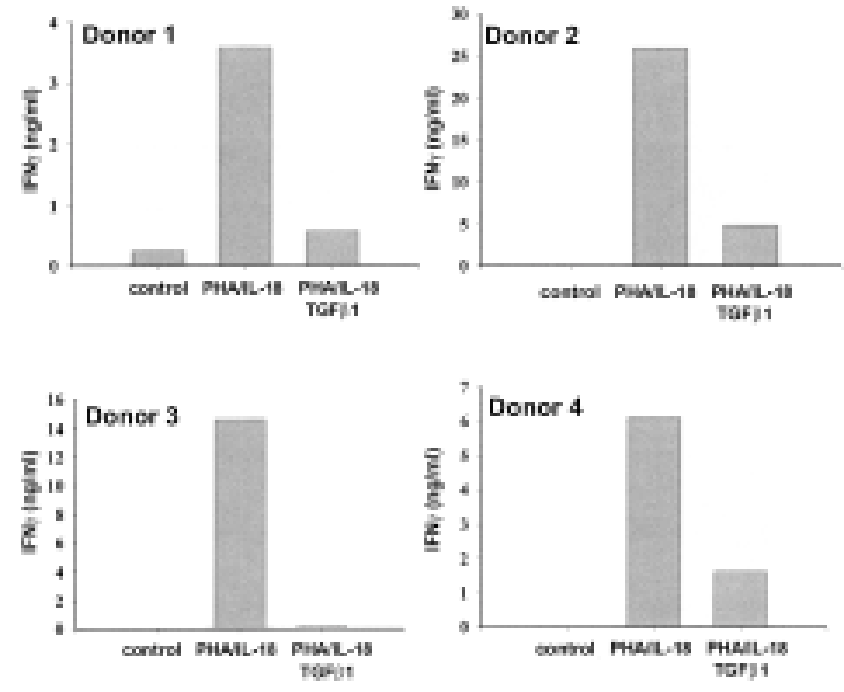

B
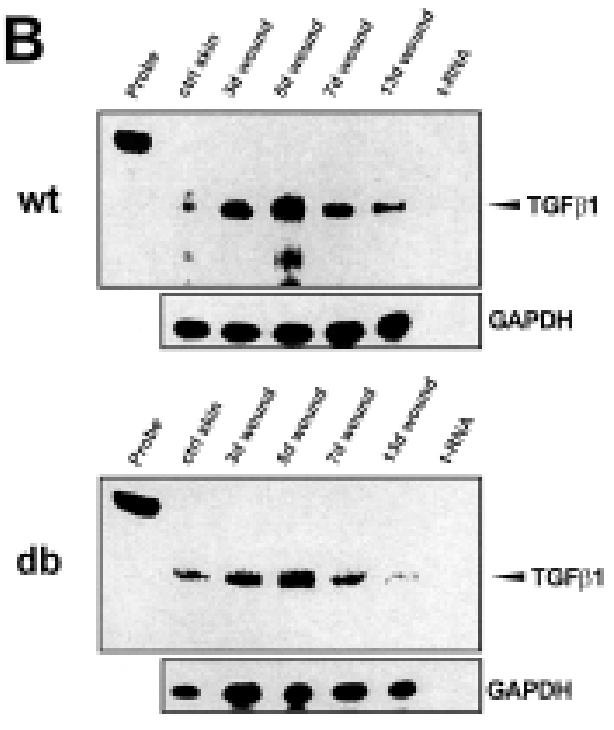

Fig. 5. TGF- $\beta 1$ as a negative regulator of IFN- $\gamma$ release. (A) Freshly isolated PBMC from different donors (donor 1 to 4 ) were stimulated by PHA $(1 \mu \mathrm{g} / \mathrm{ml}) / \mathrm{IL}-18(8 \mathrm{ng} / \mathrm{ml})$ for $24 \mathrm{hr}$ in the presence or absence of TGF- $\beta 1(10 \mathrm{ng} / \mathrm{ml})$ to investigate IFN- $\gamma$ release from the cells. Interferon- $\gamma$ secreted into the cell culture supernatants was determined by ELISA. Control represents the conditions for unstimulated PBMC. The varying amounts of secreted IFN- $\gamma$ were due to interindividual differences. (B) Total cellular RNA $(20 \mu \mathrm{g})$ from normal and wounded back skin was analyzed by

Fibroblasts located within the developing granulation tissue are characterized by three main capacities: proliferation, migration, and production of extracellular matrix. As the fibroblasts invade the wound site and become activated, an important change in cellular behavior occurs: the wound fibroblasts switch on protein synthesis. As the migratory phenotype subsequently changes into a profibrotic phenotype, an extensive protein synthesis machinery is turned on in the cells that are now characterized by large amounts of rough endoplasmic reticulum, and the Golgi apparatus filled with collagen (40). One growth factor with outstanding regulatory potency concerning regulation of fibroblast matrix production represents TGF- $\beta 1$. During granulation tissue formation, TGF- $\beta 1$ is highly expressed in wound fibroblasts (38). This might resemble a potent autocrine stimulatory mechanism, as fibroblasts produce large amounts of collagen after TGF$\beta 1$ stimulation $(41,42)$. After deposition of the collagen-matrix, fibroblasts down-regulate their matrix synthesis despite the presence of TGF- $\beta 1$ at the wound site. An important factor
RNase protection assay for expression of TGF- $\beta 1$. The pattern of TGF- $\beta 1$ mRNA expression in normal Balb/c mice (upper panel, indicated as $w t$ ), or diabetic animals (lower panel, indicated as $d b$ ) is shown. Sixteen wounds $(n=16)$ from the backs of four animals were excised for each experimental time point and used for RNA isolation. The time after injury is indicated at the top of each lane. Control skin refers to nonwounded skin of mice. One thousand cpm of the hybridization probe were added to the lane labeled probe. Expression of GAPDH is shown as a loading control.

for down-regulating fibroblast matrix synthesizing activities during late granulation might be represented by IFN- $\gamma$. In vitro studies clearly demonstrated that IFN- $\gamma$ potently attenuates type I and type III procollagen mRNA levels in human skin fibroblasts (3). The counterregulatory potencies of IFN- $\gamma$ with respect to fibroblast collagen synthesis is further reflected by its capacity to efficiently readjust elevated collagen production of cultured sclerodema fibroblasts to normal levels (2). Moreover, several in vivo studies revealed an inhibitory effect of IFN- $\gamma$ on skin collagen synthesis. Subcutaneous implantation of small osmotic pumps into mice was characterized by a subsequent fibrotic process that finally covered the implants by fibrous tissue. Delivery of IFN- $\gamma$ from these pumps, interestingly, clearly reduced the collagen deposition (11). Additionally, using a murine wound-healing model, systemic administration of IFN- $\gamma$ resulted in a markedly decreased amount of fibrillar collagen bundles compared to placebo-treated control animals. In addition, the spaces between the collagen fibers were increased and filled with acid 
mucopolysaccharides (12). This IFN- $\gamma$-directed effect was as pronounced also in 21 day wounds which were characterized by smaller and less distinct collagen bundles (12). Nevertheless, a direct report demonstrating the availability of IFN- $\gamma$ at the wound site, which might indeed strengthen the proposed antifibrotic actions of IFN- $\gamma$ during repair, is still not available. Indirect contributions have been made by determination of infiltrating lymphocyte cell numbers at the wound site. Especially, the Th 1 subtype might represent the IFN- $\gamma$-releasing cellular source at the wound site, as these cells are known to secrete IFN- $\gamma$ (16). Natural killer (NK) cells, which are stimulated for an enhanced cytotoxicity and IFN- $\gamma$ production by an IL-18 costimulation (29), are not central to a normal repair process (43). By contrast, suppressed NK cell activity has been reported after experimental injury and, moreover, in clinical studies from thermal and traumatic injuries $(44,45)$ suggesting that impaired NK cell function might contribute to the increased susceptibility to posttraumatic infection rather than to participate in IFN- $\gamma$ production. It has long been known that T-lymphocytes peak between day 5 and 7 after injury $(17,18)$. These are exactly the time points when extensive fibroblastderived collagen synthesis needs to undergo a tight counterregulatory control during repair. Thus, it is tempting to speculate that T-cellderived IFN- $\gamma$ might represent a potent mediator counterregulating the profibrotic conditions that are well described to be mediated by TGF- $\beta$ I (39). Even IL-18-driven IFN- $\gamma$ release from macrophages (13) might be discussed to precede T-cell secreted IFN- $\gamma$ during repair, as macrophage cell numbers peak at day 3 postwounding (46; see Fig. 1). Remarkably, we observed an opposite effect, as TGF- $\beta 1$ potently attenuated IL-18-triggered PBMC-derived IFN- $\gamma$ release in vitro. The observed strong TGF- $\beta$ I-mediated decrease in IFN- $\gamma$ production was consistent with a previous report from Espevik et al. (47). This correlation would imply a completely different interaction between the profibrotic TGF- $\beta 1$ and the antifibrotic IFN$\gamma$ at the wound site. The large induction of TGF- $\beta 1$ upon injury ( 38 ; this study) might be responsible for the suppression of IFN- $\gamma$ by infiltrating T-cells. This hypothesis fits the observation that depletion of TGF- $\beta 1$ from cutaneous wounds results in a markedly reduced collagen I and collagen III deposition compared to control animals (39). Moreover, this work from
Shah et al. (39) strongly suggests that the observed expression of TGF- $\beta 1$ during repair (38; this study) is translated into biologically active TGF- $\beta 1$, as specific inhibition of TGF- $\beta 1$ actions at the wound site by exogenous application of TGF- $\beta 1$ neutralizing antibodies further resulted in reduction of fibronectin deposition, a reduced macrophage profile, and reduced wound vascularization. Accordingly, the TGF$\beta$ s have been clearly implicated as important factors driving cellular proliferation, differentiation, and migration pivotal to cutaneous wound healing $(48,49)$. Thus, one might speculate that, at least partially, the loss of active TGF- $\beta 1$ in this experimental setup leads to an increase in IFN- $\gamma$ in the wound, which then exerts its antifibrotic actions. This potential mechanism is further supported by the observation that systemic treatment of rats or mice with polyinisinic-polycytidylic acid resulted in enhanced closure rates of cutaneous wounds, which were accompanied by an observed increase of TGF- $\beta 1$ expression associated with elevated collagen I and collagen III expression (50).

On the other hand, one has to consider that IL-18, like IL- $1 \beta$, has to be processed from its immature proform to gain biologic activity. Thus, as the detected IL-18 protein during repair was most likely to represent the immature precursor (see Fig. 1), this phenomenon might provide a second explanation for the observed lack of IFN- $\gamma$-inducing activities at the wound site. However, pro-IL-1 $\beta$ and pro-IL-18 might share more proteinases than the described IL$1 \beta$-converting enzyme (ICE) $(51,52)$ that are capable of releasing the mature cytokines from their inactive precursors. Especially for inflammatory conditions, proteases such as chymase (33), cathepsin, and elastase (34), or even matrix metalloproteinases (MMP) (35) have been shown to process IL- $1 \beta$ independent from the ICE pathway. As MMPs are highly expressed by keratinocytes during the inflammatory and reepithelialization phase of wound repair (36) and also expression of chymase could be observed (this study), it is tempting to speculate that the large amounts of pro-IL-18, which are recognized by the antibody (Fig. 1), will be processed, at least to small amounts, by woundderived proteases in the context of repair.

The absence of IFN- $\gamma$, at least below detectable amounts (this study), during repair obviously raises a second important question: What physiological actions are mediated by 
IL-18 during tissue repair? Initially described as IFN- $\gamma$-inducing factor (IGIF) (53), IL-18 primarily serves the biologic function as a costimulant for Th 1 cell cytokine production by acting as a costimulant for IFN- $\gamma$ production with IL-12, IL-2, microbial agents, or mitogens $(54,55)$. For normal healing, we observed large amounts of IL-18 protein after injury (20; this study), but maximal IL-18 induction levels (day 3) clearly preceded maximal T-cell infiltration (day 7) at the wound site. Nevertheless, IL-18 levels still remained elevated when T-cells arrive. Moreover, diabetes-impaired healing, which is characterized by a prolonged inflammatory phase, revealed large amounts of IFN- $\gamma$-co-inducing IL-18. However, for both healing conditions, we could not detect any IFN- $\gamma$ present within the wounds. In this context, it is worth noting that IL-18 is reported to induce tumor necrosis factor- $\alpha$, IL- $1 \beta$, and both CXC and CC chemokines (56), thus placing IL-18 among other proinflammatory cytokines as a most likely contributor to local inflammation. This is in line with a very recent report that demonstrated intradermal injection of an IL-18 cDNA under control of the constitutive CMV promoter led to production of IL-18 in dermal cells which was subsequently followed by a massive infiltration of immune cells into the skin (57). Additionally, this observation indeed suggests that the constitutive intradermal expression of pro-IL- 18 protein from the encoding cDNA finally led to an in situ conversion of the IL-18 precursor protein into a biologically active form. Thus, one has to consider that IL-18 indeed does not serve its well-described IFN- $\gamma$-inducing capabilities during cutaneous wound repair, but is most likely to provide additional, but yet unknown functions during tissue-regeneration processes.

\section{Acknowledgments}

We thank Nicole Kolb for her excellent technical assistance. We gratefully acknowledge Dr. Martin Kock for his help regarding the animal experiments. This work was supported by a grant of the Adolf Messer-Stiftung.

\section{References}

1. Jimenez SA, Freundlich B, Rosenbloom J. (1984) Selective inhibition of human diploid fibroblast collagen synthesis by interferons. J. Clin. Invest. 74: 1112-1116.

2. Duncan MR, Berman B. (1987) Persistence of a reduced-collagen-producing phenotype in cultured scleroderma fibroblasts after short term exposure to interferons. J. Clin. Invest. 79: 13181324.

3. Czaja MJ, Weiner FR, Eghbali M, Giambrone $M$, Eghbali M, Zern MA. (1987) Differential effects of gamma-interferon on collagen and fibronectin gene expression. J. Biol. Chem. 262: 13348-13351.

4. Granstein RD, Flotte TJ, Amento EP. (1990) Interferons and collagen production. J. Invest. Dermatol. 95: 75-80.

5. Fleischmajer R, Perlish JJ, Duncan M. (1983) Scleroderma: a model for fibrosis. Arch. Dermatol. 119: 957-962.

6. Murray JC, Pollack SV, Pinnell SR. (1981) Keloids: a review. J. Am. Acad. Dermatol. 4: 461470.

7. Symington FW. (1989) Lymphotoxin, tumor necrosis factor, and gamma interferon are cytostatic for normal human keratinocytes. J. Invest. Dermatol. 92: 798-805.

8. Scheynius A, Fransson J, Johansson C, Hammar H, Baker B, Fry L, Valsimarsson H. (1992) Expression of interferon-gamma receptors in normal and psoriatic skin. J. Invest. Dermatol. 98: 255-258.

9. Hein R, Behr J, Hundgen M, et al. (1992) Treatment of systemic sclerosis with gamma-interferon. Br. J. Dermatol. 126: 496-501.

10. Hunzelmann N, Anders S, Fierlbeck G, et al. (1997) Systemic scleroderma. Multicenter trial of 1 year of treatment with recombinant interferon gamma. Arch. Dermatol. 13: 609-613.

11. Granstein RD, Murphy GF, Margolis RJ, Byrne MH, Amento EP. (1987) Gamma interferon inhibits collagen synthesis in vivo in the mouse. J. Clin. Invest. 79: 1254-1258.

12. Granstein RD, Deak MR, Jacques SL, et al. (1989) The systemic administration of gamma interferon inhibits collagen synthesis and acute inflammation in a murine skin wounding model. J. Invest. Dermatol. 93: 18-27.

13. Munder M, Mallo M, Eichmann K, Modolell M. (1998) Murine macrophages secrete interferon- $\gamma$ upon combined stimulation with interleukin (IL)-12 and IL-18: a novel pathway of autocrine macrophage activation. J. Exp. Med. 187: 21032108.

14. Howie SEM, Aldridge RD, McVittie E, Forsey RJ, Sands C, Hunter JAA. (1996) Epidermal keratinocyte production of interferon- $\gamma$ immunoreactive protein and mRNA is an early event in allergic contact dermatitis. J. Invest. Dermatol. 106: 1218-1223.

15. Mosmann TR, Cherwinski H, Bond MW, Giedlin MA, Coffman RL. (1986) Two types of murine helper $\mathrm{T}$ cell clone. I. Definition accord- 
ing to profiles of lymphokine activities and secreted proteins. J. Immunol. 136: 2348-2357.

16. Mosmann TR, Coffman RL. (1989) TH1 and TH2 cells: different patterns of lymphokine secretion lead to different functional properties. Annu. Rev. Immunol. 7: 145-173.

17. Fishel RS, Barbul A, Beschorner WE, Wasserkrug HL, Efron G. (1987) Lymphocyte participation in wound healing: morphologic assessment using monoclonal antibodies. Ann. Surg. 206: 25-29.

18. Ross R, Benditt EP. (1962) Wound healing and collagen formation. Fine structure in experimental scurvy. J. Cell Biol. 12: 533-548.

19. Efron JE, Frankel FL, Lazarou SA, Wasserkrug HL, Barbul A. (1990) Wound healing and Tlymphocytes. J. Surg. Res. 48: 460-463.

20. Kämpfer H, Kalina U, Mühl H, Pfeilschifter J, Frank S. (1999) Counterregulation of interleukin18 mRNA and protein expression during cutaneous wound repair in mice. J. Invest. Dermatol. 113: 369-374.

21. Coleman DL. (1982) Diabetes-obesity syndromes in mice. Diabetes 31: 1-6.

22. Chen H, Charlat O, Tartaglia LA, et al. (1996) Evidence that the diabetes gene encodes the leptin receptor: identification of a mutation in the leptin receptor gene in $d b / d b$ mice. Cell 84: 491-495.

23. Lee GH, Proenca R, Montez JM, Carroll KM, Darvishzadeh JG, Lee JI, Friedman JM. (1996) Abnormal splicing of the leptin receptor in diabetic mice. Nature 379: 632-635.

24. Chomczynski P, Sacchi N. (1987) Single-step method of RNA isolation by acid guanidinium thiocyanate-phenol-chloroform extraction. Anal. Biochem. 162: 156-159.

25. Werner S, Peters KG, Longaker MT, Fuller-Pace F, Banda MJ, Williams LT. (1992) Large induction of keratinocyte growth factor expression in the dermis during wound healing. Proc. Natl. Acad. Sci. USA 89: 6896-6900.

26. Gray PW, Goeddel DV. (1983) Cloning and expression of murine immune interferon cDNA. Proc. Natl. Acad. Sci. USA 80: 5842-5846.

27. Chu W, Johnson DA, Musich PR. (1992) Molecular cloning and characterization of mouse mast cell chymases. Biochem. Biophys. Acta 1121: 83-87.

28. Mühl H, Dinarello CA. (1997) Macrophage inflammatory protein-1 alpha production in lipopolysaccharide-stimulated human adherent blood mononuclear cells is inhibited by the nitric oxide synthase inhibitor N(G)-monomethylL-arginine. J. Immunol. 159: 5063-5069.

29. Akira S. (2000) The role of IL-18 in innate immunity. Curr. Opin. Immunol. 12: 59-63.

30. Wetzler C, Kämpfer H, Stallmeyer B, Pfeilschifter J, Frank S. (2000) Large and sustained induction of chemokines during impaired wound healing in the genetically diabetic mouse: prolonged persistance of neutrophils and macrophages during the late phase of repair. J. Invest. Dermatol. 115: 245-253.
31. Maddon PJ, Molineaux SM, Maddon DE, et al. (1987) Structure and expression of the human and mouse T4 genes. Proc. Natl. Acad. Sci. USA 84: 9155-9159.

32. Austyn JM, Gordon S. (1981) F4/80, a monoclonal antibody directed specifically against the mouse macrophage. Eur. J. Immunol. 11: 805-815.

33. Mizutani H, Schechter N, Lazarus G, Black RA, Kuppers TS. (1991) Rapid and specific conversion of precursor interleukin $1 \beta$ (IL-1 $\beta$ ) to an active IL- 1 species by human mast cell chymase. $J$. Exp. Med. 174: 821-825.

34. Hazuda DJ, Strickler J, Kueppers F, Simon PL, Young PR. (1990) Processing of precursor interleukin $\mathrm{l} \beta$ and inflammatory disease. J. Biol. Chem. 265: 6318-6322.

35. Schonbeck U, Mach F, Libby P. (1998) Generation of biologically active IL- $1 \beta$ by matrix metalloproteinases: a novel caspase-1-independent pathway of IL-1 $\beta$ processing. J. Immunol. 161: 3340-3346.

36. Martin P. (1997) Wound healing-aiming for perfect skin regeneration. Science 276: 75-81.

37. Eckes B, Aumailley M, Krieg T. (1996) Collagens and the reestablishment of dermal integrity. In: Clark RAF (ed.) The Molecular and Cellular Biology of Wound Repair. Plenum Press, New York, pp. 493-512.

38. Frank S, Madlener M, Werner S. (1996) Transforming growth factors $\beta 1, \beta 2$, and $\beta 3$ and their receptors are differentially regulated during normal and impaired wound healing. J. Biol. Chem. 271: 10188-10193.

39. Shah M, Foreman DM, Ferguson MWJ. (1995) Neutralisation of TGF- $\beta 1$ and TGF- $\beta 2$ or exogenous addition of TGF- $\beta 3$ to cutaneous rat wounds reduces scarring. J. Cell Sci. 108: 985-1002.

40. Welsh MP, Odland GF, Clark RAF. (1990) Temporal relationships of F-actin bundle formation, collagen and fibronectin matrix assembly, and fibronectin receptor expression to wound contraction. J. Cell. Biol. 110: 133-145.

41. Ignotz RA, Massague J. (1986) Transforming growth factor- $\beta$ stimulates the expression of fibronectin and collagen and their incorporation into extracellular matrix. J. Biol. Chem. 261: 4337-4340.

42. Roberts AB, Sporn MB, Assoian RK, et al. (1986) Transforming growth factor $\beta$ : rapid induction of fibrosis and angiogenesis in vivo and stimulation of collagen formation. Proc. Natl. Acad. Sci. USA 83: 4167-4171.

43. Schäffer M, Barbul A. (1998) Lymphocyte function in wound healing and following injury. $\mathrm{Br}$. J. Surgery 85: 444-460.

44. Pollock RE, Babcock GF, Romsdahl MM, Nishioka K. (1984) Surgical stress-mediated suppression of murine natural killer cell cytotoxicity. Cancer Res. 44: 3888-3891.

45. Blazar BA, Rodrick ML, O'Mahony JB, Wood JJ, Bessey PQ, Wilmore DW, Mannick JA. (1986) 
Suppression of natural killer-cell function in humans following thermal and traumatic injury. J. Clin. Immunol. 6: 26-36.

46. DiPietro LA. (1995) Wound healing: the role of the macrophage and other immune cells. Shock 4: 233-240.

47. Espevik T, Figari IS, Shalaby MR, Lackides GA, Lewis GD, Shepard HM, Palladino MA. (1987) Inhibition of cytokine production by cyclosporin A and transforming growth factor $\beta$. J. Exp. Med. 166: 571-576.

48. Roberts AB. (1995) Transforming growth factor$\beta$ : activity and efficacy in animal models of wound healing. Wound Repair Regen. 3: 408-418.

49. O'Kane S, Ferguson MW. (1997) Transforming growth factor $\beta \mathrm{s}$ and wound healing. Int. J. Biochem. Cell Biol. 29: 63-78.

50. Sidhu GS, Thaloor D, Singh AK, Raghunath PN, Maheshwari RK. (1996) Enhanced biosynthesis of extracellular matrix proteins and TGF- $\beta 1$ by polyinosinic-polycytidylic acid during cutaneous wound healing in vivo. J. Cell Physiol. 169: 108-114.

51. Ghayur T, Banerjee S, Hugunin M, et al. (1997) Caspase-1 processes IFN- $\gamma$-inducing factor and regulates LPS-induced IFN- $\gamma$ production. Nature 386: 619-623.
52. Gu Y, Kuida K, Tsutsui H, et al. (1997) Activation of interferon- $\gamma$ inducing factor mediated by interleukin- $1 \beta$ converting enzyme. Science 275: 206-209.

53. Nakamura $K$, Okamura $H$, Wada $M$, Nagata $K$, Tamura T. (1989) Endotoxin-induced serum factor that stimulates $\gamma$ interferon production. Infect. Immunol. 57: 590-595.

54. Kohno K, Kataoka J, Ohtsuki T, et al. (1997) IFN- $\gamma$-inducing factor (IGIF) is a co-stimulatory factor on the activation of Th1 but not Th2 cells and exerts its effects independently of IL-12. J. Immunol. 158: 1541-1550.

55. Robinson D, Shibuya K, Mui A, et al. (1997) IGIF does not drive Thl development but synergizes with IL-12 for interferon- $\gamma$ production and activates IRAK and NF $\mathrm{B}$. Immunity 7: 571-581.

56. Puren AJ, Fantuzzi G, Gu Y, Su MS, Dinarello CA. (1998) Interleukin-18 (IFN $\gamma$-inducing factor) induces IL-8 and IL- $1 \beta$ via TNF alpha production from non-CD14+ human blood mononuclear cells. J. Clin. Invest. 101: 711-721.

57. Kremer L, Dupre L, Wolowczuk I, Locht C. (1999) In vivo immunomodulation following intradermal injection with DNA encoding IL-18. J. Immunol. 163: 3226-3231. 